\title{
Silica diagenesis and its effect on porosity of upper Maastrichtian chalk - an example from the Eldfisk Field, the North Sea
}

\author{
Heine Buus Madsen
}

Diagenetic precipitation of silicate minerals such as quartz and clay minerals can reduce the permeability and porosity of chalk as they precipitate as cement in pores (e.g. Taylor \& Lapré 1987; Maliva \& Dickson 1992). However, the precipitation can also result in early lithification and help to preserve porosity during burial.

Several studies of diagenesis have been carried out on chalk samples from the North Sea oil fields (e.g. Scholle 1977; Maliva \& Dickson 1992; Hancock 1993) but only a few have focused on silica diagenesis (Fabricius \& Borre 2007; Fabricius et al. 2007). Silica is not a major constituent of chalk but is abundant in some intervals where it influences the reservoir properties, as seen for example in the Ekofisk Formation and in a few intervals in the underlying Tor Formation in the Eldfisk and Ekofisk fields. This distribution may indicate that the variations are linked to facies and palaeo-oceanography; the silica either representing diagenetically reprecipitated biogenic silica, volcanic ash falls or a high input of detrital minerals (Scholle 1977; Kennedy 1987; Fabricius \& Borre 2007).

This paper discusses diagenesis of quartz- and kaoliniterich intervals in the deeply buried upper Maastrichtian chalk of the upper Tor Formation (TA layer) in core 2/7-B-12 A from the Eldfisk Field in the Norwegian sector of the North Sea (Fig. 1). The study was carried out as part of a $\mathrm{PhD}$ project at the Geological Survey of Denmark and Greenland and the Department of Geography and Geology, University of Copenhagen (Madsen 2009). The objective of the study was to understand the processes leading to formation and enrichment of quartz and kaolinite and the resulting influence on porosity.

\section{Lithology and mineralogy}

The upper Tor Formation consists of grey bioturbated chalk with stylolites, argillaceous solution seams and a few marly layers in the studied core (Fig. 2). A single firmground is present at $10480 \mathrm{ft}$. The chalk is usually almost pure carbonate with $96-97 \%$ calcite. The insoluble residue mainly consists of quartz and kaolinite, with small amounts of illite-smectite, feldspar, fluor-apatite, crandelite $\left(\mathrm{CaAl}_{3}\left(\mathrm{PO}_{4}\right)_{1.5}(\mathrm{OH}) \cdot 5 \mathrm{H}_{2} \mathrm{O}\right)$, dolomite, pyrite and fluorite.
However, up to $12 \%$ insoluble residue is present in two intervals at $10420-10431$ and $10470-10480 \mathrm{ft}$. The $10420-$ $10431 \mathrm{ft}$ interval contains abundant stylolites, and overall the insoluble residue consists of the same minerals as in the pure chalk. The 10 470-10 $480 \mathrm{ft}$ interval only contains few marly layers and stylolites, and the insoluble residue in this interval is dominated by kaolinite and quartz.

Quartz occurs as euhedral crystals, aggregates and subhedral crystals. The euhedral crystals are six-sided and doubleterminated by six-faced pyramids up to $10 \mu \mathrm{m}$ long (Fig. 3A). Both crystals and aggregates are commonly associated with kaolinite. The quartz crystals commonly sit on kaolinite crystals but may also enclose the kaolinite (Fig. 3C). In the 10 420-10 $431 \mathrm{ft}$ interval the subhedral quartz crystals, up to $25 \mu \mathrm{m}$ in size, enclose recrystallised coccolith fragments and older quartz crystals. The subhedral quartz crystals only show few well-developed crystal faces, commonly with imprints from recrystallised coccolith fragments.

Kaolinite occurs as hexagonal crystals arranged in booklets, commonly around $5 \mu \mathrm{m}$ in diameter (Fig. 3A-C). The kaolinite is found both in voids and as part of the matrix. It is often associated with quartz aggregates and single quartz crystals (Fig. 3A, B). Energy-dispersive X-ray spectroscopy

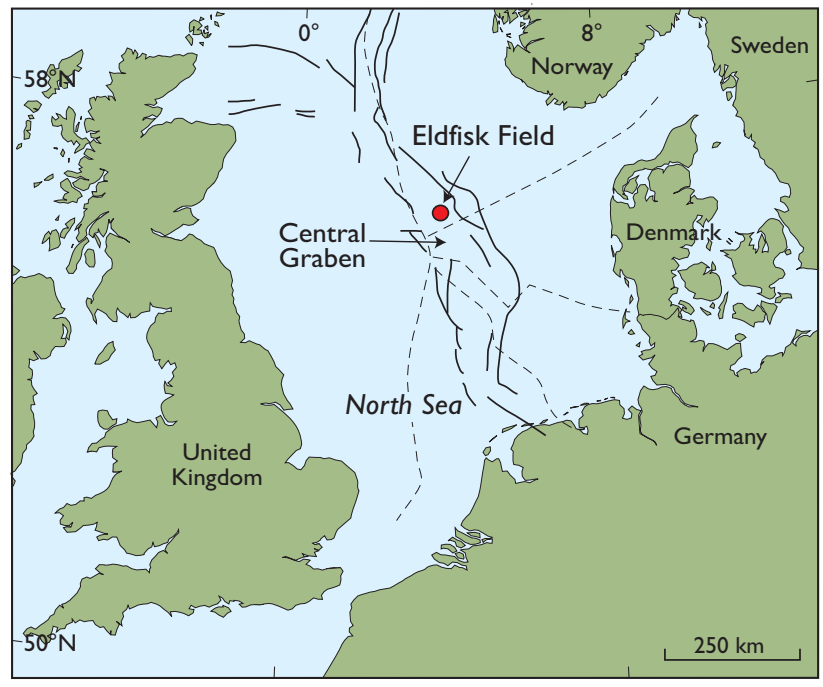

Fig. 1. Map of the North Sea region showing structural elements and the location of the Eldfisk Field. Dashed lines: national borders. 


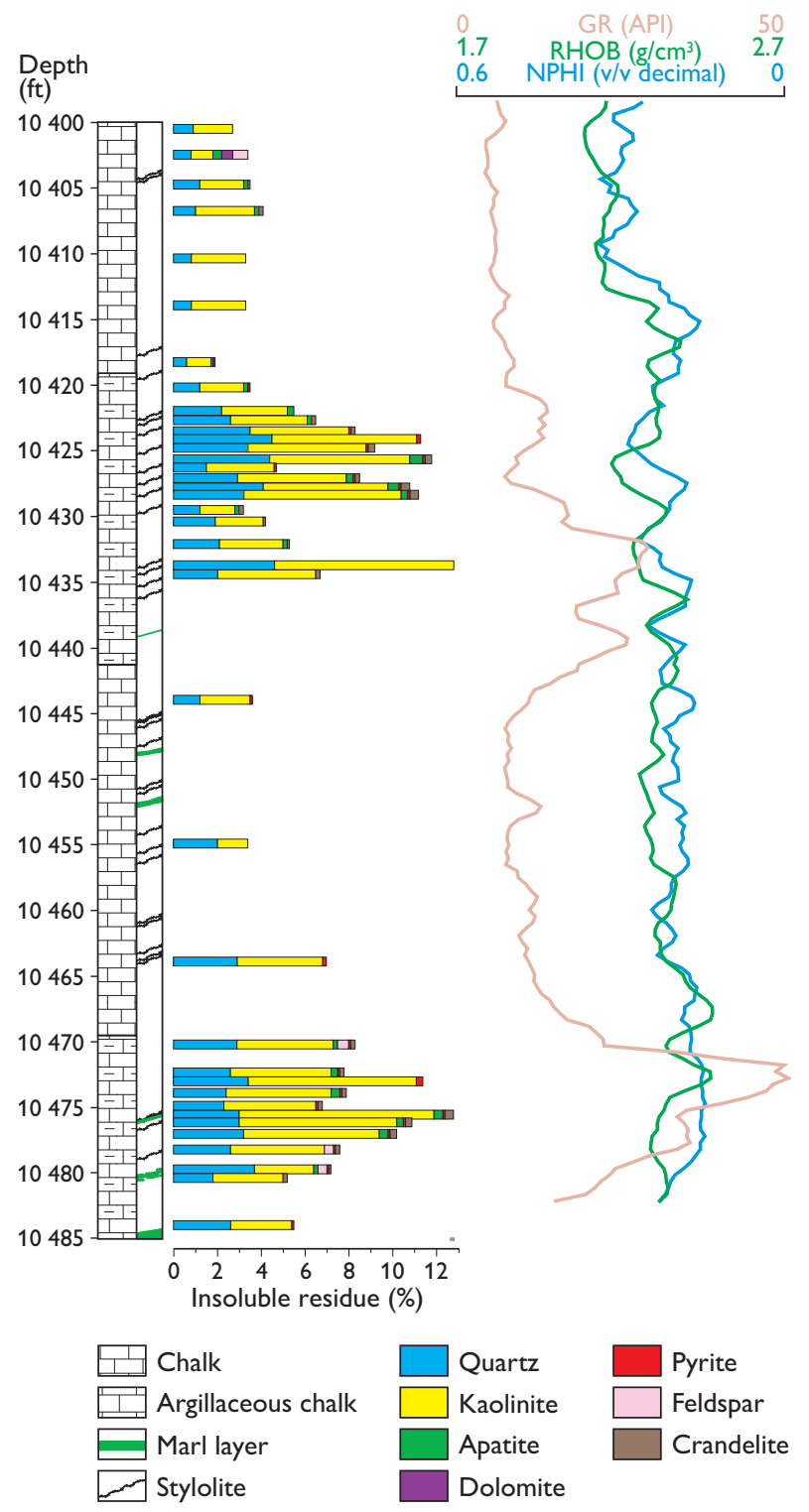

Fig. 2. Lithological and petrophysical logs of the upper part of the Tor Formation, showing the 10 400-10 $495 \mathrm{ft}$ interval in the 2/7-B-12 A core.

analyses show that the kaolinite primarily consists of $\mathrm{Si}$, $\mathrm{Al}$ and $\mathrm{O}$. Illite-smectite is present in trace amounts in all samples analysed by X-ray diffraction. It has a delicate, flaky morphology (Fig. 3D) and contains small amounts of $\mathrm{K}$ and $\mathrm{Mg}$ in addition to $\mathrm{Si}, \mathrm{Al}$ and $\mathrm{O}$.

\section{Petrophysical characteristics of intervals rich in insoluble residue}

In order to determine the petrophysical properties of the intervals high in insoluble residue, petrophysical logs, litho- logical variations and mineralogy were compared with each other. The interval 10 420-10 $431 \mathrm{ft}$ contains much more quartz and kaolinite than the surrounding chalk. The lower part of the interval shows high gamma-ray values (GR; Fig. 2). The neutron log (NPHI) and density log (RHOB) responses are similar to the surrounding chalk. High GR values are also seen below the $10420-10431 \mathrm{ft}$ interval, indicating that the interval rich in insoluble residues extends down to $10440 \mathrm{ft}$. In the $10470-10480 \mathrm{ft}$ interval high GR values correlate with high contents of kaolinite and quartz, whereas no obvious peaks in NPHI and RHOB can be related to changes in the mineralogy (Fig. 2).

A neutron $\log$ versus density log plot of the studied succession shows that the chalk mainly plots between the sandstone and limestone trends (Fig. 4). This is due to the presence of hydrocarbons which are lighter than saline pore water. Both intervals rich in insoluble residue and the chalk between 10 415-10 $485 \mathrm{ft}$ have higher density and lower porosity than the upper interval at $10400-10415 \mathrm{ft}$. The estimated porosity of the chalk in the $10400-10415 \mathrm{ft}$ interval is around $35 \%$ whereas the quartz- and kaolinite-rich intervals have porosities around 25\% (Fig. 4). The high gammaray values (dark-brown plus signs) represent clay-rich parts and have estimated porosities of $20-25 \%$.

\section{Silicate diagenesis}

The quartz and kaolinite may either have derived from detrital grains or from devitrification of volcanic ash. However, the latter produces bentonite which is dominated by illite and montmorillonite. Hence, volcanic ash cannot be the source. Weathering products such as smectite, kaolinite, quartz and feldspar from the nearby Baltic Shield are a more likely source for the quartz and kaolinite as also suggested by Kennedy (1987). The distribution of quartz and kaolinite in the two insoluble-rich intervals also indicates an event of longer duration than a volcanic eruption. However, some of the authigenic quartz probably originated from phase transformations of biogenic opal-A to opal-CT and finally to quartz.

The occurrence of long booklets of kaolinite indicates that some of it precipitated from solution (Fig. 3B). But the close association between quartz and kaolinite seen in the scanning electron microscope images indicates that they originated from mineral reactions (Fig. 3A, C). The disappearance of smectite and the formation of illite with depth are well known in the Central Graben in the North Sea and in other sedimentary basins (Compton 1991; Abercrombie et al. 1994; Drits et al. 1997). However, since kaolinite is the most abundant clay mineral in the studied interval, a slight- 
Fig. 3. Scanning electron microphotographs of chalk samples illustrating components of the insoluble residue. A: Double-terminated quarts crystal (Q) sitting on kaolinite (K). B: Quartz aggregates (lower left corner $(\mathbf{Q})$, consisting of sub-micron sized quartz crystals) and booklets of kaolinite $(\mathbf{K})$. C: Kaolinite $(\mathbf{K})$ embedded in quartz (Q). D: Flaky illite-smectite (Is).
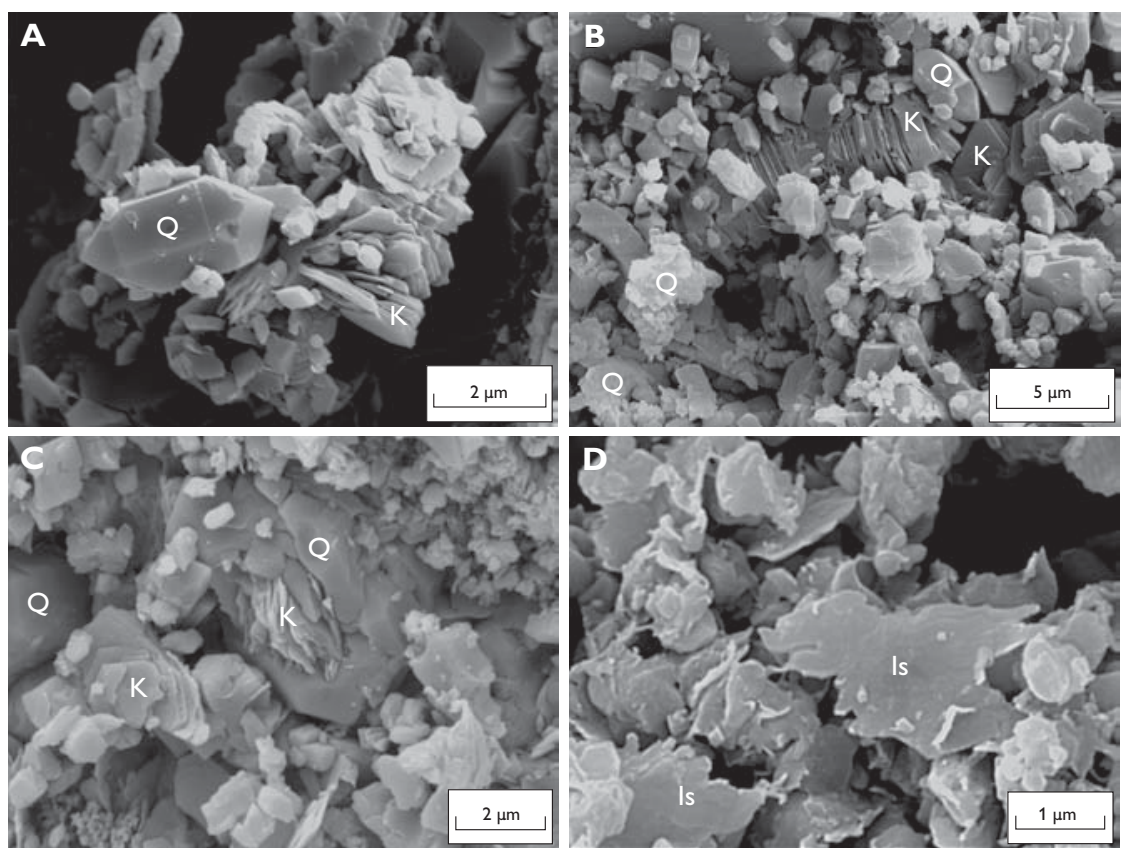

ly different mineral reaction is suggested where smectite is mainly transformed to kaolinite, following the equation:

smectite + K-feldspar $\rightarrow$ kaolinite + quartz + illite-smectite

The formation of kaolinite and illite-smectite is probably the result of release of $\mathrm{Mg}$ and $\mathrm{Fe}$ from the octahedral layer and Si from the tetrahedral layer in the smectite (Hower $e t$ al. 1976), which enables precipitation of quartz near the kaolinite as seen in Fig. 3. During this transformation aluminium is preserved in the structure (Compton 1991). The released $\mathrm{Mg}$ and $\mathrm{Fe}$ must have diffused away because only small amounts of dolomite or other $\mathrm{Mg}$ - and Fe-rich minerals are observed in the chalk (Fig. 2). Alternatively the smectite was originally poor in $\mathrm{Mg}$ and $\mathrm{Fe}$.

Additional potassium, from K-feldspar or other sources is needed to form smectite-illite (Hoffman \& Hower 1979; Compton 1991). The fact that kaolinite is the most common authigenic clay mineral indicates that detrital potassiumrich minerals were rare. However, dissolution of potassiumrich minerals has probably contributed with $\mathrm{Al}, \mathrm{Si}$ and some $\mathrm{K}$ to the formation of kaolinite and smectite-illite, with excess $\mathrm{Si}$ precipitating as quartz. The mineral assemblage with kaolinite and quartz indicates a potassium-poor system, but the high gamma-ray values recorded in the two insoluble-rich intervals imply that minerals containing potassium or other radiogenic elements are indeed present (Fig. 2).

\section{Porosity reduction}

Due to a high primary content of detrital smectite and illitesmectite in the 10 420-10 431 and 10 470-10 $480 \mathrm{ft}$ intervals, the primary sorting and hence the initial porosities were lower than in the surrounding chalk. The neutron log versus density log plot (Fig. 4) shows an estimated porosity of c. 35\% for samples of pure chalk (the $10400-10415 \mathrm{ft}$ interval), and porosities of c. 27\% and 22\% for the 10 420-10 431 and $10470-10480 \mathrm{ft}$ intervals that are rich in insoluble residue. This confirms that the content of detrital minerals had a great effect on the initial porosities. However, precipitation of quartz and kaolinite in pores reduced the porosity further.

\section{Conclusions}

Two intervals with high contents of insoluble residue, up to $12 \%$, were found in the upper Tor Formation in the 2/7-B-12 A core from the Eldfisk Field. The insoluble residue primarily consists of authigenic quartz and kaolinite with subordinate illite-smectite. The kaolinite, illite-smectite and quartz formed both by precipitation from solution and by mineral reactions during burial. The release of $\mathrm{Mg}, \mathrm{Fe}$ and $\mathrm{Si}$ and the addition of $\mathrm{Al}$ in the crystal latice of detrital smectite resulted in a mineral reaction that formed most of the kaolinite. Dissolution of feldspar contributed $\mathrm{Al}$, and the released $\mathrm{Si}$ precipitated as quartz at or near the kaolinite. The intervals represent potassium-poor systems where kaolinite precipitat- 


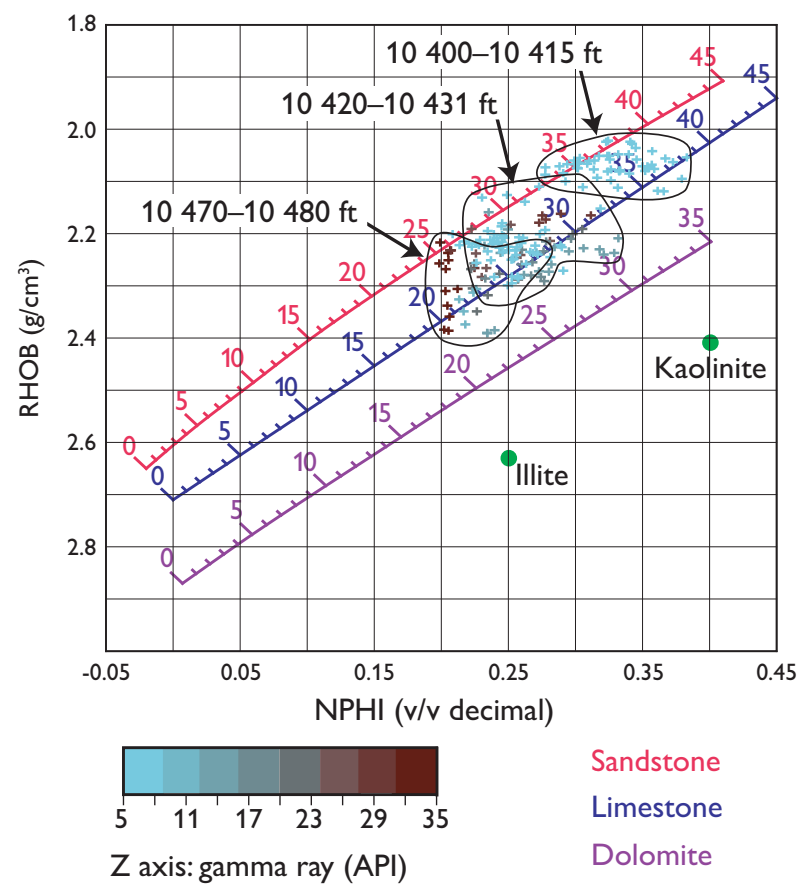

Fig. 4. NPHI versus RHOB plot of the 10 400-10 $495 \mathrm{ft}$ interval in core 2/7-B-12 A from the Eldfisk Field. Trends for sandstone, limestone and dolomite porosities are shown for comparison. The pure chalk at $10400-$ $10420 \mathrm{ft}$ mostly shows high estimated porosities (c. 35\%), whereas the lower section and the intervals rich in insoluble residue show lower porosities. The dark brown coloured data points reflect high gammaray value samples, which also have the lowest estimated porosities (the $10470-10480 \mathrm{ft}$ interval).

ed rather than illite-smectite. The high content of insoluble residue in the $10420-10431 \mathrm{ft}$ and $10470-10480 \mathrm{ft}$ intervals was probably caused by a high content of detrital minerals, causing poor sorting and lower porosities compared to the more pure chalk. Precipitation of kaolinite and quartz caused a minor additional reduction of the porosity in the insoluble residue-rich intervals.

\section{Acknowledgements}

ConocoPhillips Norway is thanked for financial support and for providing core material and geophysical logs.

\section{References}

Abercrombie, H.J., Hutcheon, I.E.. Bloch, J.D. \& Decaritat, P. 1994: Silica activity and the smectite-illite reaction. Geology 22, 539-542.

Compton, J.S. 1991: Origin and diagenesis of clay minerals in the Monterey Formation, Santa Maria Basin area, California. Clays and Clay Minerals 39, 449-466.

Drits, V.A., Sakharov B.A., Lindgreen, H. \& Salyn, A. 1997: Sequential structure transformation of illite-smectite-vermiculite during diagenesis of Upper Jurassic shales from the North Sea and Denmark. Clay Minerals 32, 351-371.

Fabricius, I.L. \& Borre, M.K. 2007: Stylolites, porosity, depositional texture, and silicates in chalk facies sediments. Ontong Java Plateau Gorm and Tyra fields, North Sea. Sedimentology 54, 183-205.

Fabricius, I.L., Røgen, B. \& Gommesen, L. 2007: How depositional texture and diagenesis control petrophysical and elastic properties of samples from five North Sea chalk fields. Petroleum Geoscience 13, 81-95.

Hancock, J.M. 1993: The formation and diagenesis of chalk. In: Downing, R.A., Price, M. \& Jones, G.P. (eds): The hydrogeology of the chalk of North-West Europe, 14-34. New York: Oxford University Press.

Hoffman, J. \& Hower, J. 1979: Clay mineral assemblages as low grade metamorphic geothermometers: application to the thrust faulted disturbed belt of Montana, U.S.A. In: Scholle, P.A. \& Schluger, P.R. (eds): Aspects of diagenesis. Society of Economic Paleontologists and Mineralogists (SEPM) Special Publications 26, 55-79.

Hower, J., Eslinger, E.V., Hower, M. \& Perry, E.A. 1976: The mechanism of burial metamorphism of argillaceous sediments: 1. Mineralogical and chemical evidence. Geological Society of America Bulletin 87, 725-737.

Kennedy, W.J. 1987: Sedimentology of Late Cretaceous-Paleocene chalk reservoirs, North Sea Central Graben. In: Brooks, J. \& Glennie, K.W. (eds): Petroleum geology of North West Europe, 469-481. Proceedings of the 3rd conference on petroleum geology of North West Europe. London: Graham \& Trotman.

Madsen, H.B. 2009: Microbial and burial induced silica diagenesis in Upper Cretaceous - Paleogene chalk in Denmark and the North Sea. PhD thesis, University of Copenhagen, Denmark. Danmarks og Grønlands Geologiske Undersøgelse Rapport 2009/41, 33 pp.

Maliva, R.G. \& Dickson, J.A.D. 1992: Microfacies and diagenetic controls of porosity in Cretaceous/Tertiary chalks, Eldfisk, Norwegian North Sea. AAPG Bulletin 76, 1825-1838. Tulsa, Oklahoma: American Association of Petroleum Geologists.

Scholle, P.A. 1977: Chalk diagenesis and its relation to petroleum exploration. AAPG Bulletin 61, 982-1009. Tulsa, Oklahoma: American Association of Petroleum Geologists.

Taylor, S.R. \& Lapré, J.F. 1987: North Sea chalk diagenesis: its effect on reservoir location and properties. In: Brooks, J. \& Glennie K.W. (eds): Petroleum geology of North West Europe, 483-495. Proceedings of the 3rd conference on petroleum geology of North West Europe. London: Graham \& Trotman.

\footnotetext{
Author's address

Geological Survey of Denmark and Greenland, Øster Voldgade 10, DK-1350 Copenhagen K, Denmark. E-mail: heinebuus@yahoo.com
} 